\title{
Rola narracji filozoficznej w etyce cnót środowiskowych
}

\author{
The Role of Philosophical Narration in Environmental Virtue Ethics
}

\author{
Dominika Dzwonkowska \\ Instytut Filozofii, Uniwersytet Kardynała Stefana Wyszyńskiego w Warszawie \\ ORCID: https://orcid.org/0000-0002-2060-2901・d.dzwonkowska@uksw.edu.pl \\ Zgłoszono: 12.02.2021; zrecenzowano: 19.04.2021; zaakceptowano do druku: 21.04.2021
}

\begin{abstract}
Streszczenie: Etyka cnót środowiskowych jest stosunkowo młodym obszarem badań, który podejmuje zagadnienie moralnych dyspozycji wspierających działania na rzecz ochrony środowiska. W niniejszym artykule przedstawiam i porządkuję tezy narracyjnej koncepcji etyki cnót środowiskowych. Celem moich analiz jest ukazanie podwójnej roli narracji w tej koncepcji etyki, to jest zarówno jako narzędzia transformacji indywidualnej, jak i społecznej. Takie ujęcie odpowiada rodzajom dyspozycji moralnych, w koncepcji Briana Treanora, twórcy narracyjnej etyki cnót. Przeprowadzone analizy pomogły pokazać narrację, jako narzędzie do poznawania siebie samego, a dokładniej odpowiadania na pytanie: kim jestem? By móc zdefiniować i dążyć do tego, kim chcę się stać. W ten sposób autonarracja staje się narzędziem osobistej przemiany (metanoi). Narracja nie tylko służy rozwojowi osobistemu, lecz także poprzez język mitów, metafor i obrazów wspiera promowanie pożądanych kodów kulturowych. W ten sposób narracja jest bardzo skutecznym narzędziem przemiany społecznej. Kluczowe w narracji są dwa narzędzia. Po pierwsze, na poziomie indywidualnym, istotne jest phronesis, które pomaga wybierać dobrą narrację i odpowiednio ją interpretować. Drugim narzędziem, ważnym na poziomie społecznym, jest edukacja moralna, która pozwala kształtować postawy moralne służące rozwojowi społeczeństwa w pożądanym kierunku.
\end{abstract}

Słowa kluczowe: etyka cnót środowiskowych, cnoty środowiskowe, narracja, phronesis, edukacja moralna

\begin{abstract}
Environmental virtue ethics is quite a new area of research that undertakes the issue of moral dispositions enabling actions for environmental protection. In this article, I shall present and organise the claims of narrative, environmental, virtue ethics. The aim of my analysis is to highlight the dual role of narration in this concept of ethics, which can be used as a tool for individual and social transformation. This approach corresponds to the types of moral dispositions, within the concept formed by Brian Treanor, the author of the narrative virtues ethics. The analyses carried out, helped to show the narrative as a tool allowing to get to know oneself and, or more precisely, to answer the question: who am I? To be able to define and pursue what I want to become. In this way, auto-narration becomes a tool of personal transformation (metanoi). Narration not only serves personal development, but through the language of myths, metaphors, and images, supports the promotion of desired cultural codes. In this way, narration is a very effective tool for social transformation. Two instruments are key in narration. First, on an individual level, phronesis is important to help to choose a good narrative and interpret it in the proper way. The second tool, important at the social level, is moral education, which helps to shape the moral attitudes for the development of society in the desired direction.
\end{abstract}

Keywords: environmental virtue ethics, environmental virtue, narration, phronesis, moral education 


\section{Wstęp}

Etyka cnót środowiskowych (ecś) podejmuje zagadnienia aretologiczne z perspektywy naszych zobowiązań moralnych wobec środowiska przyrodniczego. Jednym z narzędzi mówienia o cnotach jest propozycja narracyjnej koncepcji etyki cnót środowiskowych Briana Treanora, inspirowana wcześniejszymi dyskusjami aretologicznymi, jak i pracami na temat roli narracji w rozwoju moralnym (głównie dorobkiem Paula Ricoeura). Treanor uważa, że odpowiednia narracja może pomóc podmiotowi moralnemu dążyć do dobrego charakteru moralnego, jak i sprzyjać krzewieniu pożądanych postaw moralnych w społeczeństwie (część 2).

Celem niniejszego artykułu jest uporządkowanie poglądów Treanora na temat narracji poprzez pokazanie dwóch jej funkcji, to jest stymulowania rozwoju moralnego na poziomie indywidualnym i społecznym. Cel ten zostanie zrealizowany na tle ukazania krótkiego wprowadzenia do dyskusji aretologicznych w etyce środowiskowej (część 1). Ponadto w trzeciej części artykułu zaprezentowane zostaną wybrane słabości i zarzuty wobec narracyjnej koncepcji ecś wraz z próbą odpowiedzi na nie.

\section{Wprowadzenie do etyki cnót środowiskowych}

Od lat 7o. XX wieku filozofowie interesują się problematyką ekologiczną, analizując relację człowieka ze środowiskiem naturalnym z perspektywy ekofilozofii i etyki środowiskowej. Ta druga dyscyplina w literaturze anglosaskiej sięgała najczęściej do dwóch sposobów uprawiania etyki normatywnej: tradycji deontologicznej i konsekwencjonalistycznej (głównie utylitarystycznej). Mimo że te dwa podejścia dostarczają wartościowych rozstrzygnięć i uzasadnień dla norm etycznych, to skupiają się głównie na naturze czynu moralnego, pomijając kwestię charakteru i intencji podmiotu moralnego. Owe pominięte kwestie stały się przedmiotem tzw. etyki cnót środowiskowych, która powstała na fali renesansu zainteresowania problematyką aretologiczną obecnego w filozofii od lat 50. XX wieku' Za symbolicznego twórcę ecś uchodzi Thomas Hill Jr., to on jako pierwszy opublikował tekst poświęcony cnotom środowiskowym ${ }^{2}$, tj. tym dyspozycjom moralnym, które pomagają człowiekowi chronić środowisko naturalne. Niemniej problematyka aretologiczna była obecna w etyce środowiskowej od samego jej początku, a nawet w nurcie, który zainspirował etykę środowiskową - transcendentalizmie amerykańskim (Cafaro 2010).

W ramach ecś w literaturze anglosaskiej powstały trzy samodzielne koncepcje filozoficzne: 1) klasyczna etyka cnót środowiskowych autorstwa Henry'ego Davida Thoreau (1854) w interpretacji Philipa Cafaro (2004); 2) naturalistyczna, teleologiczna i pluralistyczna koncepcja etyki cnót środowiskowych zaproponowana przez Ronalda Sandlera (2007) oraz 3) narracyjna koncepcja etyki cnót środowiskowych stworzona przez Briana Teranora (2014). W Polsce zagadnienie cnót zostało przedstawione w kilku moich publikacjach, w tym między innymi w monografii prezentującej koncepcję uniwersalistycznej, pozytywnej i praktycznej etyki cnót środowiskowych (2019). Dodatkowo ważnym wkładem w rozwój dyscypliny jest analiza języka cnót środowiskowych dokonana przez Louke van Wensveen (2000).

Każda z wymienionych powyżej koncepcji proponuje oryginalną interpretację ujęcia problematyki aretologicznej w etyce środowiskowej. Podejmują one próbę pokazania troski o środowisko z perspektywy charakteru moralnego człowieka oraz najbardziej pożądanych dyspozycji moralnych, które służą ochronie środowiska. Tym samym uzupełniają dotychczasowe dyskusje, które skupiały się na kwalifikacji moralnej czynu, odwołując się do jego natury bądź

1 Renesans cnót przypisywany jest Gertrudzie E.M. Anscombe (1958), która w artykule Modern Moral Philosophy krytykuje etykę deontologiczną i konsekwencjonalistyczną, wykazując ich słabości, zachęca do zainteresowania etyką cnót.

2 Chodzi o artykuł Ideals of Human Excellence and Preserving Natural Environment (1983). 
konsekwencji płynących z danego działania. Należy zaznaczyć, że wkład w rozwój dyscypliny miało również wielu niewymienionych tu autorów, którzy nie zostali ujęci ze względu na zawężenie poruszanego tutaj problemu do narracji ${ }^{3}$

W niniejszym artykule przedmiotem analizy będzie narracyjna propozycja etyki cnót środowiskowych, która upatruje w narracji narzędzie do rozwoju moralnego człowieka. Wiele z jej założeń jest ciekawych i interesujących, szczególnie wartościowy jest praktyczny wymiar tej koncepcji, która stawia nacisk na doskonalenie cnót zarówno na poziomie indywidualnym, jak i w formie szerszego programu skierowanego na edukację moralną. W następnej części niniejszego artykułu przyjrzę się narracji jako narzędziu, które pomaga w rozwijaniu moralności. Skupię się szczególnie na kwestii realizacji naszych zobowiązań wobec środowiska naturalnego.

\section{Narracyjna koncepcja etyki cnót środowiskowych}

Twórcą narracyjnej koncepcji etyki cnót środowiskowych jest Brian Treanor ${ }^{4}$, który zauważa, że dyskusja o cnotach nie jest łatwym zadaniem, ale $\mathrm{z}$ pomocą $\mathrm{w}$ jego realizacji przychodzi narracja rozumiana jako pewien sposób opowieści o cnotach i dążeniu do nich. Kluczową filozoficzną pracą

3 Szczegółowy opis w języku polskim prezentujący powstanie ecś, jej rozwój i przedstawicieli, charakter i zarzuty wobec niej można znaleźć w książce Etyka cnót środowiskowych (Dzwonkowska 2019). W języku angielskim prac przybliżających ecś jest bardzo dużo, na szczególne wyróżnienie zasługują prace Cafaro (2010, 2015) oraz zbiorowa monografia Environmental Virtue Ethics (pod redakcją Sandlera i Cafaro 2005).

4 Brian Treanor urodził się w Kalifornii, obecnie jest zatrudniony jako profesor filozofii w Bellarmine College of Liberal Arts. Od 2014 roku pełni funkcję Dyrektora Akademii Katolickiej myśli i twórczości na Uniwersytecie Loyola w Marymont. Naukowo zajmuje się filozofią hermeneutyczną, ale jego badania mają charakter interdyscyplinarny i obejmują analizy z obszaru teologii, literatury, poezji, psychologii, czy ekologii. poświęconą narracji, źródłem inspiracji dla Treanora, jest dzieło Ricoeura Temps et récit, przełożone na angielski pod tytułem Time and Narrative (1983). Użyte tu pojęcie narracji jest rozumiane ,jako struktura znaczenia, rozwijająca się w czasie - pojawia się w rozważaniach nad tożsamością jednostki i zbiorowości ludzkiej, nad statusem poznawczym historiografii, charakterystyką ontologiczną przedmiotu badań historycznych, we współczesnych reinterpretacjach procedur psychoanalitycznych czy wreszcie w analizach fikcji literackich" (Rosner 2003, 129). Ricoeur twierdzi, że narracja to kody wypracowane przez kulturę, dzięki nim rozumiemy nasze doświadczenia, a przede wszystkim możemy zrozumieć siebie samych.

\subsection{Narracja jako narzędzie do osobistej przemiany}

Treanor, wzorując się na Ricoeurze, podkreśla rolę narracji w rozumieniu siebie i poprzez to $\mathrm{w}$ kształtowaniu własnego charakteru moralnego. Przede wszystkim jednak narracja pomaga nam dowiedzieć się kim jesteśmy, ponieważ „zrozumieć samego siebie, to być zdolnym do opowiadania o samym sobie historii zrozumiałych i zarazem możliwych do przyjęcia przez innych" (Ricoeur 1992a, 58). Zdaniem Ricoeura można wyróżnić 2 rodzaje tożsamości: idem oraz ipse. „Idem (łac. idem, ang. sameness, niem. Gleichheit) - tożsamości tego, co jednakowe, rozumianej jako bycie tym samym, oraz ipse (łac. ipse, ang. selfhood, niem. Selbstheit) tożsamości samego siebie, czyli bycie sobą rozumiane jako możność działania" (Karczyńska 2014, 67). To co odróżnia od siebie te dwa pojęcia tożsamości, to trwałość w czasie, idem jest czymś trwałym, co nie podlega zmianom w czasie, podczas gdy ipse jest zmienne. Narracja w pewien sposób pośredniczy między idem i ipse. Przybliża nam te dwie tożsamości siebie samego, opowiadając o nich, w ten sposób dowiadujemy się o tym, kim jesteśmy jako my sami, a zmiennemu ipse narracja nadaje cechy trwałego charakteru, co też pozwala nam zdobyć wiedzę o sobie samym. Narracja o sobie samym pozwala nam uporządkować nasze 
doświadczanie świata i połączyć to w jedną spójną całość, w osobę, którą jestem i która działa w świecie.

Treanor widzi w narracji narzędzie do osobistej przemiany osiąganej dzięki pielęgnowaniu cnót. Owa przemiana osoby, w świecie antycznym określana jako metanoia, jest owocem przemyślenia (noeo) czegoś (meta). W świecie antycznym metanoia jest głęboką przemianą osobowości, niekiedy interpretowaną w kontekście religijnym jako nawrócenie. U Treanora owa przemiana służy wykształceniu cnót, które pomogą rozwiązać najważniejszy problem dwudziestego pierwszego wieku - postępującą degradację środowiska naturalnego (Treanor 2014, 22). Jego zdaniem narracja powinna wzbudzać w podmiocie moralnym chęć przemiany i pokazywać możliwości jej dokonania. Nieco wbrew przyjętym w świecie akademickim tendencjom, by rozważać złożone problemy teoretyczne ${ }^{5}$, stawia on za cel swoich prac pomaganie ludziom, aby wiedli bardziej etyczne życie (Treanor 2014, 23). Tym samym wraca w swoich publikacjach do pytań zadawanych w etyce starożytnej: jak żyć dobrze; co to znaczy dobre życie; jak żyć, by realizować dobro w sensie etycznym.

Dlaczego narracja może skutecznie przyczyniać się do dobrego życia? Dlatego, że nasz umysł jest bardziej podatny na jej przyswajanie. Narracja przemawia do nas

5 Treanor krytykuje ową tendencję, jego zdaniem prace wielu etyków stały się zbyt oderwane od życia moralnego i niezrozumiałe dla przeciętnej, nawet wykształconej, osoby. Uważa, że w ten sposób etyka odsunęła się od codziennego życia. Podkreśla, że - jego zdaniem - rozważania w zakresie szeroko rozumianej filozofii moralności powinny być dostępne dla wszystkich, w przeciwieństwie do nauk ścisłych. Nieznajomość bowiem fizyki nie sprawi, że nasze życie będzie gorsze, jest szereg osób, które dzięki wiedzy z zakresu nauk ścisłych sprawiają, że nasze życie staje się lepsze. Niemniej z moralnością jest inaczej, każdy musi sam indywidualnie decydować o swoich wyborach moralnych, stąd konieczne jest tworzenie koncepcji etycznych, które są dostępne dla każdego, by móc bardziej świadomie dokonywać wyborów moralnych. obrazami i metaforami. Jest pewnego rodzaju etycznym skrótem (Treanor 2014, 157), który mówi podmiotowi moralnemu, co dobra osoba zrobiłaby w danej sytuacji. Narracja wykorzystuje myślenie obrazami, a zdaniem Treanora zdolność do tego jest typowo ludzką cechą i odróżnia nas od innych bytów (Treanor 2014, 22). Narracja posługuje się także metaforami, które dokonują „przeniesienia” - metapherein - prawdziwego i zdawałoby się niemożliwego metabasis eis allo genos, przejścia od jednego stanu egzystencjalnego, jakim jest myślenie, do innego, jakim jest bycie zjawiskiem wśród zjawisk, a to może być dokonane jedynie przez analogie. „Nie ma analogii między, powiedzmy, zachodem słońca a wiekiem podeszłym i gdy poeta mówi o starości jako "zachodzie życia", to ma on na myśli relację zachodzącego słońca w stosunku do minionego dnia, którą przyrównuje on do starości odniesionej do całego życia" (Arendt 1979, 171). W ten sposób zjawisko znane nam wszystkim pokazuje za pomocą obrazu treści, jakie chce przedstawić autor dzieła.

Mit, metafora i obraz są istotnymi elementami, które scalają kultury, na przykład wokół pojęcia państwowości, wokół szacunku do tych samych świąt, tradycji i bohaterów narodowych. Powyżej wymienione są przykładami metanarracji, która jednoczy wiele osób wokół wspólnie wyznawanych idei. Innym, istotnym zdaniem Treanora, przykładem meta-narracji są religie, które obficie sięgają do obrazów i metafor, za pomocą nich przekazują złożone koncepcje moralne w przystępny sposób. Również w literaturze ekofilozoficznej pojawia się odniesienie do systemów religijnych służące promowaniu ideałów ekologicznych. W literaturze przedmiotu (Cafaro 2004, 71-75) podkreśla się, że struktura książki H.D. Thoreau jest zainspirowana kompozycją wielkiej epopei hinduskiej - Bhagawadgity. Podobieństwa nie kończą się na strukturze, można zauważyć, że metaforyczna walka na polu Kurukszetry, opisana w epopei jako symbol walki dobra ze złem, jest inspiracją dla opisów doświadczeń Thoreau i interpretacji ich 
w kategoriach walki ze złem. Owym złem są własne słabości, które proste i szlachetne życie filozofa ma pomóc przezwyciężyć. Takie zakamuflowane opowieści o dobru są znacznie skuteczniejszą motywacją do czynienia dobra niż złożone wypowiedzi teoretyczne. Stąd narracja staje się ważnym elementem mówienia o cnotach środowiskowych, tj. tych sprawnościach moralnych, które mają odniesienie do naszej relacji ze środowiskiem przyrodniczym i które powinniśmy rozwijać w sobie.

Mit i metafora są częścią kultur archaicznych, ale są także stosowane w filozofii, zdaniem Arendt $(1979,172)$ wręcz wszystkie pojęcia filozoficzne są metaforami, dla których zrozumienia konieczne jest odwołanie się do analogii tych pojęć $\mathrm{z}$ ich oryginalnymi odpowiednikami. Jako przykład filozofka podaje duszę Platońską, jako tchnienie, oddech życia i wreszcie niewidzialny organ człowieka, który u starożytnego myśliciela staje się ideą, czyli formą czy wzorcem. Platon chętnie odwoływał się też do mitów, jego dialogi obfitują w szereg obrazowych przedstawień jego koncepcji. Zdaniem Wolickiej $(1994,58)$ mit u Platona jest świadomą formą wprowadzania i przedstawiania prawd metafizycznych.

Mit i metafora od dawna są zatem ważną częścią filozofii, a zdaniem Arendt, wręcz nieodzownym elementem jej języka. Według Treanora mogą one służyć nie tylko do przedstawiania prawd metafizycznych, lecz także do przekazywania treści etycznych. Zresztą sama narracja nie jest neutralna aksjologicznie, odwołuje się bowiem w swojej treści do określonych wartości. Stąd stwarza ogromne możliwości wykorzystania jej jako narzędzia osobistej przemiany, jak i inspirowania innych do doskonalenia moralnego. Narracja jest narzędziem do przechodzenia od tego kim jestem, do tego kim chcę się stać. Zdaniem Treanora (2014, 110) narracja w pierwszej kolejności pomaga odpowiedzieć na Sokratejskie pytanie: kim jestem. Tak jak przedstawiono powyżej w myśli Ricoeura, narracja pomaga nam odkryć swoją tożsamość i dowiedzieć się, jaką każdy z nas jest osobą. Niemniej w autorefleksyjnej narracji nie kończymy na tym etapie, proces przemiany życia składa się z opisu, narracji i preskrypcji (Ricoeur 1992b, 114-115). Ostatni etap przyczynia się do stawania się najlepszą wersją samego siebie. Treanor zaznacza (2014, 161), że każdy ma wyobrażenie siebie, do którego dąży. Dzięki narracji możemy doskonalić siebie oraz zapewnić sobie dobre życie.

Ostatni etap autorefleksji pozwala nam rozpoznać, czego potrzebujemy, by móc się rozwijać i dzięki temu osiągnąć szczęście takim, jakim jest opisywane w różnych koncepcjach etyki cnót. Celem zmiany osobowej i pielęgnowania cnót jest osiągnięcie szczęścia, czyli eudajmonizmu. Treanor (2014, 25-26), zainspirowany filozofia Arystotelesa, przyjmuje eudajmonistyczną i teleologiczną koncepcję etyki cnót środowiskowych. Odpowiedź na pytanie, co to znaczy być dobrym człowiekiem, widzi właśnie w osiągnięciu szczęścia poprzez praktykowanie cnót, jedynie taka forma szczęścia jest trwała i zapewnia poczucie trwałego spełnienia w życiu człowieka. Treanor podkreśla za Arystotelesem rolę rozumowania w osiąganiu szczęścia w życiu. Jak podkreśla Stagiryta, rozum jest kluczowy w osiągnięciu szczęścia, bowiem „dobro człowieka realizuje się przez rozwijanie w sobie przymiotów (cnót) właściwych dla człowieka, a więc przymiotów intelektu/rozumu (cnót intelektualnych) oraz przymiotów woli (cnót moralnych)" (Zawojska 2017, 5-6). Owo dobro człowieka jest rozumiane u Arystotelesa jako szczęście. Gwarantem szczęścia jest zatem postępowanie zgodnie z cnotą i naturą człowieka, w tym takie działanie, które uwzględnia jego racjonalność.

\subsection{Narracja jako narzędzie przemiany społecznej}

Jak pokazano powyżej, narracja służy do doskonalenia podmiotu moralnego, wyzwala chęć przejścia od tego kim jestem, do tego kim mogę być. Tak aby każdy, zgodnie z założeniami etyki eudajmonistycznej, stawał się najlepszą wersją siebie samego. Niemniej Treanor krytykował dotychczasową 
etykę cnót środowiskowych za brak zaangażowania w kwestie społeczne i w swojej koncepcji ecś stawia nie tylko na indywidualny rozwój. Otóż narracja powinna pomagać także w kształtowaniu postaw społecznych poprzez kształtowanie wyobrażeń na temat kodów kulturowych. Jest to możliwe, dlatego że przekazuje ona, co jest moralnie akceptowalne, lub co jest uznawane za złe w danej kulturze. Owe kody kulturowe są przekazywane przez tradycje ludowe, legendy, mity czy baśnie powtarzane z pokolenia na pokolenie.

Treanor widzi rolę nośnika kodów świata zachodniego w bajkach Ezopa, a kultur dalekowschodnich w buddyjskich opowieściach - Díataka ${ }^{6}$ lub hinduskich baśniach - Pańćatantra ${ }^{7}$. Jednym z głównych narzędzi przekazu jest pokazywanie wzorca moralnego, jakim jest tak zwany paradygmatyczny charakter moralny. Jest to postać, która prezentuje wzorcowe zachowania moralne i na podstawie analizy sposobu jej działania można poznać odpowiedź na pytanie: jak należy postępować w danej sytuacji. Wymienione powyżej pozycje również odwołują się do bohaterów moralnych, np. Dżataka wskazuje na Buddę jako wzorzec moralny, do którego powinniśmy dążyć. Tak zwany wzorcowy charakter moralny ma kluczowe znaczenie w ecś (Dzwonkowska 2018a). Sandler (2005) wręcz uważa, że obserwowanie osób, które odegrały znaczącą rolę w ochronie środowiska, jest jednym z najlepszych sposobów na zdecydowanie, co jest cnotą środowiskową i rozpoznanie, jak należałoby postąpić w danej sytuacji. Narracja dostarcza zatem informacji potrzebnych do określenia, czy dane działanie jest cnotliwe czy też nie. Warto zaznaczyć, że mimo iż narracja odwołuje się do kodów kulturowych określonej tradycji, nie oznacza to, że wartości i cnoty właściwe tej tradycji są zasadniczo różne od cnót i wartości w innych

6 Jest to zbiór opowieści o życiu Buddy, które przekazują jego nauczanie w sposób prosty i zrozumiały dla najmłodszych czytelników.

7 Baśnie hinduskie, które powstały między IV a III wiekiem p.n.e. tradycjach. Cnoty, a szczególnie cnoty środowiskowe, mają wymiar uniwersalny ${ }^{8}$, to znaczy, że wiele odmiennych kultur uznaje te same cnoty za kluczowe dla rozwoju moralności człowieka, co więcej - istota cnót jest rozumiana tak samo w odmiennych kulturach.

Treanor widział tutaj ogromne znaczenie przekazów kulturowych w kształtowaniu społeczeństwa, zresztą podkreślał też rolę metanarracji (np. narracji religijnej bądź narracji związanej z przynależnością do danej kultury) w kształtowaniu postaw społecznych. Podkreślał, że kultura zachodnia nie służy rozwijaniu metanarracji, globalizacja i homogenizacja kultury wręcz promują odrzucanie wzorców związanych z przynależnością do określonego kręgu kulturowego $(2014,92)$, a postępująca laicyzacja społeczeństw zachodnich powoduje odrzucanie narracji religijnych. Dlatego też powstaje pewnego rodzaju pustka po dotychczasowych wielkich metanarracjach, a przez to pojawia się przestrzeń do powstania nihilizmu i relatywizmu. Treanor uważa, że etyka cnót środowiskowych może, a nawet powinna, wypełnić ową przestrzeń po utraconych wielkich narracjach kulturowych, ma ona możliwość zaproponowania narracji, która będzie uznawana w różnych kulturach, służąc rozwoju indywidualnemu i społecznemu. Szczególnie podkreślał rolę wybranych koncepcji z myśli Marty Nussbaum (2001), Ronalda Sandlera (2007) oraz Alasdaira MacIntyre'a (1988), jako tych poglądów filozoficznych, które pozwalają na przezwyciężenie kulturowego relatywizmu i nihilizmu. Dzięki temu stanowią podstawę do budowania etyki cnót środowiskowych, która może wypełnić pustkę po wielkich metanarracjach. W ten sposób narracyjna etyka cnót środowiskowych może stać się kluczowym narzędziem do przemiany społecznej.

Treanor postrzegał w narracyjnej ecś potencjał do dokonania społecznych przemian

8 Bardziej rozbudowaną argumentację na temat uniwersalistycznego wymiaru cnót można znaleźć w monografii Etyka cnót środowiskowych (Dzwonkowska 2019, 264-274). 
w kierunku ochrony środowiska, postulował utworzenie tak zwanej polityki cnót (Treanor 2010, 27), która byłaby pewnego rodzaju zbiorowym działaniem umożliwiającym rozwijanie dyspozycji moralnych służących ochronie środowiska. Etyka cnót powinna bowiem służyć autentycznej przemianie społecznej w kierunku społeczeństwa dbającego o środowisko ${ }^{9}$. Postulat ten jest konsekwencją postrzegania rodzajów cnót, jakie Treanor uznaje za istotne. Otóż jego zdaniem cnoty odnoszą się do trzech obszarów rozwoju moralnego człowieka: samego siebie, innych oraz środowiska przyrodniczego (Treanor 2014, 55). Podmiot moralny dba zatem o pielęgnowanie trzech rodzajów cnót: indywidualnych, społecznych i środowiskowych.

Argumentem za podzieleniem cnót na trzy grupy jest dostrzeżenie, że są cnoty, które są ważne w jednej z wymienionych sfer, ale nie mają znaczenia dla innych. Na przykład życzliwość jest fundamentem dobrych relacji społecznych, ale nie ma wpływu na nasze działania na rzecz ochrony środowiska. Inną cnotą społeczną jest myślenie holistyczne, które pozwala na szersze spojrzenie na problemy, z którym stykamy się na co dzień. Dzięki takiemu ujęciu dostrzegamy środowisko naturalne i mamy świadomość, że powinniśmy je uwzględniać w naszych wyborach moralnych. Myślenie holistyczne jest w pewnym sensie analogiczne do patrzenia przez pryzmat założeń etyki Ziemi autorstwa Aldo Leopolda (2004) pozwala bowiem spojrzeć na nas i środowisko jako na pewnego rodzaju wspólnotę, której elementy są wzajemnie ze sobą powiązane. Taka perspektywa daje podmiotowi moralnemu komunikat, że wszelkie działania należy podejmować tak, by uwzględniać dobro innych bytów, włącznie z bytami pozaludzkimi

9 Warto zaznaczyć, że Treanor nie jest odosobniony w tym obszarze, u wielu osób pojawiał się bowiem postulat wykorzystania etyki cnót środowiskowych do tworzenia społeczeństwa opartego na zasadach zrównoważonego rozwoju (van Wensveen 2000, 2001; Newton 2003; Cafaro 2015; Dzwonkowska 2018b). i całymi ekosystemami. W myśl postulatu utworzenia określonej „polityki cnót” Treanor zakłada, że jedną z ważnych cnót społecznych jest zaangażowanie polityczne. Jego zdaniem bowiem cnoty środowiskowe nie mogą pozostawać w sferze czystej teorii, ale muszą być realizowane na szeroką skalę. To jest możliwe tylko przy zaangażowaniu decydentów, ale aby to osiągnąć, osoby zainteresowane ochroną środowiska muszą zadbać o wprowadzenie odpowiednich działań do planów zarządzania i polityki na różnych szczeblach. Ujmując sprawę jak najszerzej, cnoty społeczne służą nie tylko podmiotowi moralnemu, lecz także mają za cel szeroko rozumiany rozwój społeczeństwa i dbanie o społeczeństwo jako grupę ludzi, jak i jako wspólnotę biotyczną.

Oczywiście nie da się wydzielić różnych grup cnót z chirurgiczną precyzją i ograniczyć je do realizowania rozwoju podmiotu moralnego tylko i wyłącznie w jednym obszarze. Niektóre cnoty mają bowiem dobry wpływ na każdą ze sfer funkcjonowania człowieka, np. prostota. Służy ona jednostce, która dzięki niej może bardziej skupić się na jakości życia, a nie na jej materialnym wymiarze. Prostota służy środowisku naturalnemu i sposobowi gospodarowania zasobów, ale także pozwala na promowanie korzystnych postaw społecznych, które nie redukują człowieka do homo consumens.

Narracja odgrywa szczególną rolę w obszarze nauczania społeczeństwa, jak realizować cnoty środowiskowe, jednym bowiem z najpoważniejszych problemów jest często brak wiedzy na temat działań, które mogą służyć środowisku, lub błędna wiedza w tym zakresie. Dodatkowo sprzeczne opinie i informacje, w środkach masowego przekazu i mediach społecznościowych, na temat pewnych zjawisk (np. zmian klimatu) nie służą podejmowaniu decyzji. Narracja może zatem odegrać funkcję edukacyjną, poprzez przekazywanie rzetelnej wiedzy na tematy ekologiczne może sprzyjać kształtowaniu charakteru środowiskowego. Przede wszystkim można w niej pokazać, czy dane zjawisko zachodzi i jak - zgodnie z obecnym 
stanem wiedzy - można jemu zapobiegać bądź łagodzić jego skutki. Taka narracja jest zatem jak najbardziej pożądanym narzędziem dla każdego. Zresztą edukacja moralna jest najpotężniejszym narzędziem do przemiany społeczeństwa w społeczeństwo respektujące środowisko naturalne.

\section{Słabości narracyjnej koncepcji etyki cnót środowiskowych}

Narracyjna koncepcja ecś wydaje się być interesującym rozwiązaniem, niemniej nie jest pozbawiona pewnych słabości, nad którymi warto się zastanowić. Warto zaznaczyć jednak, że wymienione poniżej zarzuty nie podważają możliwości zastosowania tej koncepcji do wprowadzenia zmian $\mathrm{w}$ indywidualnym, jak i społecznym podejściu wobec ochrony środowiska. Trzeba bowiem podkreślić, że argumenty Treanora na rzecz narracji są dobrze przemyślane i wydaje się, że narracja może być skutecznym narzędziem do zmian w postawach pojedynczych podmiotów moralnych, jak i całych społeczeństw. Niemniej nasuwa się kilka wątpliwości, które wymagają odpowiedzi.

Przede wszystkim powstaje pytanie, w kwestii doboru odpowiedniej narracji. Otóż, co sprawia, że dana narracja jest dobra. Nawet, gdy założymy tutaj, że „dobro” narracji jest rozumiane jako jej zdolność do wywołania osobistej przemiany u zapoznającego się z nią podmiotu moralnego, to należy przyjąć, że interpretacji określonej cnoty przedstawionej w narracji może być wiele. Jeden podmiot moralny może dostrzec pozytywne cechy w narracji i zainspirować się do zmiany, z kolei inny może zwrócić uwagę na inne aspekty danej opowieści i dojść do odmiennych wniosków. Przykładem może być tutaj chociażby praca Walden, czyli życie $w$ lesie autorstwa Thoreau. Wśród etyków środowiskowych powszechna jest interpretacja tej pracy jako eposu nawołującego do prostego skromnego życia oraz pokazującego troskę o środowisko naturalne. Należy dodać też, że wzorzec zarysowany przez Filozofa z Concord jest traktowany jako inspiracja do zmian w naszym codziennym życiu, na miarę własnych możliwości. Niemniej przeczy temu przypadek Christophera Johnsona McCandlessa ${ }^{10}$, który porzucił cywilizację, by ruszyć autostopem na Alaskę i zaszyć się w leśnej głuszy. Inspiracją była dla niego postać Thoreau, którego doświadczenia nad jeziorem Walden potraktował jako zachętę do życia na łonie przyrody. Jednak jego doświadczenie okazało się tragiczne w skutkach, po 113 dniach odnaleziono go bowiem martwego w porzuconym autobusie. Mimo szlachetnych motywacji konsekwencje jego działania były tragiczne.

Treanor $(2014,163)$ widzi jednak w McCandlessie ucieleśnienie cnót. Zdaniem filozofa ów chłopak kierował się autentycznym i szczerym dążeniem do odkrycia samego siebie oraz odrzucenia konsumpcjonizmu. Podkreśla, że w narracji należy zawsze skupić się na pozytywnych cechach i na nie zwracać szczególną uwagę. Taka postawa budzi wątpliwości co do roli narracji jako narzędzia osobistej metanoi. Wzorzec McCandlessa może być bowiem postrzegany jako przejaw braku tak cenionej cnoty jak roztropność, która pomaga podmiotowi moralnemu wybrać odpowiednie cnoty adekwatne do danej sytuacji. Co więcej, nie przystaje do definicji cnoty, cnota bowiem dąży do środka jako do swojego celu (Arystoteles 2007, 1106b). Cnota jest trwałą dyspozycją, która wiąże się zachowaniem średniej miary pomiędzy dwoma skrajnościami. Ową miarę określa rozum w sposób, w jaki uczyniłby to człowiek rozsądny. Wyruszenie zatem w leśną głuszę bez odpowiedniego przygotowania nie mieści się w kategoriach cnoty. Nawet jeżeli, w co nie należy wątpić, intencje McCandlessa były czyste, to jego działanie nie było w pełni cnotliwe. Było bowiem przejawem skrajności, a cnota takową nie jest, oraz wyrazem braku rozsądku tak kluczowego dla cnotliwego życia.

Pytanie o interpretacje narracji pozostaje zatem otwarte, zresztą w literaturze

10 Opisany w książce Into the Wild (1997), która doczekała się ekranizacji w 2007 r. (polski tytuł filmu to Wszystko za życie). 
przedmiotu wskazuje się, że mogą istnieć różne interpretacje narracji, w związku z tym rozumienie jej może być odmienne u różnych osób (Zuziak 2006, 93). Z perspektywy narracji ważna jest jej spójność, w związku z tym dopowiadamy brakujące elementy tak, by nasza opowieść była spójna. Zdaniem Ricoeura (1992a, 39) nieustannie dokonujemy interpretacji i reinterpretacji naszych działań, nasza narracja nie jest neutralną obserwacją, ale jest kwestią etyczną. Tak samo jest z narracją literacką, nie jest ona neutralnym opisem zdarzeń, ale podlega interpretacji podmiotu moralnego. Stąd nawet szlachetna i wartościowa narracja, jak to było w przypadku interpretacji Waldena przez McCandlessa, może popychać do niewłaściwych działań.

Reasumując powyższe, narracja jest podatna na interpretacje, a przykład McCandlessa pokazuje, że nawet dobre wzorce moralne mogą być zinterpretowane w sposób, który nie służy rozwijaniu doskonałości moralnej, ale wręcz szkodzi podmiotowi moralnemu. Można tylko częściowo zgodzić się tezą Treanora, że nawet w takich skrajnych zachowaniach należy widzieć dobro. Częściowa zgoda oznaczałaby uznanie, że rzeczywiście bohater powieści kierował się dobrymi intencjami i szlachetnością charakteru. Niemniej konsekwencje nieprzemyślanych działań były tragiczne, a samo działanie, z powyżej przedstawionych względów, nie może być zdefiniowane jako cnota. Wybierając zatem narracje do edukacji moralnej należałoby z większą starannością analizować, czy przedstawione w niej zachowania są przejawem cnoty, czyli słusznej miary nadmiarem, a brakiem danej sprawności moralnej.

Powstaje też pytanie, czy sama narracja zadziała, czy nie jest zbyt subtelnym bodźcem, by wzbudzić chęć podmiotu moralnego do przemiany, albo wręcz zachęcić całe grupy społeczne. Jest to mocno wątpliwe, czy narracja może odegrać aż tak wielką rolę. Aby była skuteczna, należałoby bowiem w jakiś sposób zachęcić jak najwięcej osób do sięgania do odpowiedniej literatury. Jest wątpliwe, czy to jest w ogóle możliwe. Jedynym warunkiem, by narracja stała się skuteczna i dotarła do jak największej liczby odbiorców, jest włączenie odpowiednich źródeł do kształcenia formalnego i nieformalnego. Bez przemyślanej zatem i odpowiednio zaprojektowanej edukacji moralnej nie ma możliwości, aby narracja przyniosła znaczącą zmianę w postawach społecznych.

\section{Próba odpowiedzi na zarzuty}

Jak wspomniano powyżej, niniejsze zarzuty nie powinny być podstawą odrzucenia dobrego pomysłu zastosowania narracji jako narzędzia kształtowania pożądanych postaw moralnych wobec środowiska naturalnego na poziomie indywidualnym i społecznym. Odpowiednia narracja zdaje się być dobrym narzędziem do wspierania rozwoju cnót środowiskowych. Niemniej kluczowe pytanie powstaje w kwestii sformułowania „odpowiednia”. Co bowiem oznacza, że narracja jest odpowiednia? Niewątpliwie przychodzi tu z pomocą phronesis - praktyczna mądrość, która od czasów starożytnych pełni funkcję swoistego kompasu w wyborach moralnych. Treanor podkreśla, że etyka cnót nie oferuje gotowych recept $(2014,87)$. Jest to związane ze specyficznym charakterem norm etyki cnót $t^{11}$, które nie są formułowane równie precyzyjnie jak normy powstające w ramach etyk normatywnych. Nie oznacza to jednak, że nie dostarczają wiedzy na temat tego, jak postępować, ale wymagają one namysłu nad tym, które działanie będzie służyło rozwijaniu cnoty, a które może zostać uznane za niecnotliwe. Ogromne znaczenie na poziomie przemiany indywidualnej ma właśnie phronesis, które pomaga podmiotowi moralnemu podejmować odpowiednie wybory moralne. Phronesis też wspiera odpowiednie rozumienie narracji, tak by jak najbardziej służyła ona rozwijaniu

11 Więcej na ten temat w pracach Rosalind Hurtshouse (1999 oraz 2004) i w artykule Normatywność etyki cnót środowiskowych na przykładzie etyki Ronalda Sandlera. Komentarz (Dzwonkowska 2017b). 
moralności i nie prowadziła do błędnych interpretacji w stylu McCandlessa.

W kwestii efektywności narracji należy podkreślić, że może ona zadziałać jedynie w połączeniu z odpowiednią edukacją moralną, zarówno formalną, jak i nieformalną. Jest wiele przykładów efektywnych programów kształcenia w cnotach, które przyniosły korzyści indywidualne i społeczne (więcej w: Snook 2007; Dzwonkowska 2017a). Na poziomie przemiany grupowej edukacja moralna jawi się jako kluczowy instrument do osiągania szeroko zakrojonej przemiany w całych społeczeństwach.

\section{Zakończenie}

Narracja jest narzędziem poznania siebie samego, a przez to służy do wykształcenia pożądanych dyspozycji moralnych. W przypadku narracyjnej etyki cnót środowiskowych przemiana służy własnemu rozwojowi moralnemu oraz uzyskaniu społeczeństwa, w którym dba się o siebie samego, relacje interpersonalne i relacje we wspólnocie biotycznej. Narracja powinna być jednak odpowiednio dobrana, stąd na poziomie indywidualnym kluczowe znaczenie ma phronesis. Dzięki tej sprawności moralnej wiadomo, jaką narrację wybrać i jak ją interpretować, by jak najlepiej służyła podmiotowi moralnemu w dążeniu do doskonałości moralnej. Na poziomie społecznym kluczowe znaczenie ma edukacja moralna, ona bowiem pomaga w świadomy sposób kształtować pożądane postawy społeczne, które wspierają podmiot moralny we własnym rozwoju, jak i wpływają na wykształcenie dyspozycji, które służą zapewnieniu dobra wszystkich członków wspólnoty biotycznej.

\section{Bibliografia}

Anscombe, Gertruda. 1958. "Modern Moral Philosophy." Philosophy 33: 1-19.

Arendt, Hanna. 1979. „Filozofia i metafora.” Teksty: teoria literatury, krytyka, interpretacja 5: 167-187. Arystoteles. 2007. Etyka nikomachejska. Warszawa: Wydawnictwo Naukowe PWN.
Cafaro, Philip. 2004. Thoreau's Living Ethics. Walden and the Pursuit of Virtue. Athens: The University of Georgia Press.

Cafaro, Philip. 2010. "Environmental Virtue Ethics. Special Issue: Introduction." Journal of Agricultural and Environmental Ethics 1-2: 3-7.

Cafaro, Philip. 2015. "Environmental Virtue Ethics." In The Routledge Companion to Virtue Ethics, edited by Lorraine Besser-Jones, and Michael Slote, 427-444. New York: Routledge.

Dzwonkowska, Dominika. 2017a. „Cnoty i wady środowiskowe w edukacji ekologicznej." W Młodzież i jej świat: praca, ekologia, wychowanie, matżeństwo i rodzina, red. Ryszard F. Sadowski, 45-58. Warszawa: Towarzystwo Naukowe Franciszka Salezego.

Dzwonkowska, Dominika. 2017b. „Normatywność etyki cnót środowiskowych na przykładzie etyki Ronalda Sandlera. Komentarz." Avant 3: 99-108.

Dzwonkowska, Dominika. 2018a. "Jan Gwalbert Pawlikowski jako przykład wzorcowego charakteru środowiskowego." Etyka 56: 13-28.

Dzwonkowska, Dominika. 2018b. „Environmental Virtue Ethics and Sustainability." Problems of Sustainable Development 2: 139-146.

Dzwonkowska, Dominika. 2019. Etyka cnót środowiskowych. Warszawa: Wydawnictwo Naukowe UKSW.

Hill, Thomas Jr. 1983. "Ideals of Human Excellence and Preserving Natural Environment." Environmental Ethics 3: 211-224.

Hurtshouse, Rosalind. 1999. On Virtue Ethics. Oxford: Oxford University Press.

Hurtshouse, Rosalind. 2004. „Normatywna etyka cnót." W Etyka i charakter, red. Jacek Jaśtal, 191209. Kraków: Aureus.

Karczyńska, Eliza. 2014. „Odkrywanie siebie w narracji. Koncepcja tożsamości narracyjnej w myśli Paula Ricoeura i Charlesa Taylora." Humaniora. Czasopismo Internetowe 1: 65-76.

Krakauer, Jon. 1997. Into the Wild. New York: Anchor Books.

Leopold, Aldo. 2004. Zapiski z piaszczystej krainy. Bielsko-Biała: Pracownia na rzecz Wszystkich Istot. MacIntyre, Alasdair. 1998. Whose Justice? Which Rationality? Notre Dame: University of Notre Dame Press. 
Newton, Lisa. 2003. Ethics and Sustainability: Sustainable Development and the Moral Life. New Jersey: Prentice Hall.

Nussbaum, Marta. 2001. Women and Human Development: The Capabilities Approach. Cambridge: Cambridge University Press.

Ricoeur, Paul. 1983. Time and Narrative. Chicago: University of Chicago Press.

Ricoeur, Paul. 1992a. Filozofia osoby. Kraków: Wydawnictwo Naukowe PAT.

Ricoeur, Paul. 1992b. Oneself as Another. Chicago: University of Chicago Press.

Rosner, Katarzyna. 2002. „Paul Ricoeur wobec współczesnych dyskusji o narracji.” Teksty Drugie 3: 129-136.

Sandler, Ronald. 2005. "Introduction: Environmental Virtue Ethics." In Environmental Virtue Ethics, edited by Ronald Sandler, and Philip Cafaro, 3-6. Oxford: Rowman \& Littlefield Publishers, Inc.

Sandler, Ronald. 2007. Character and Environment. A Virtue-Oriented Approach to Environmental Ethics. New York: Columbia University Press.

Snook, Ivan. 2007. "Values Education in Context." In Values Education and Lifelong Learning, edited by David N. Aspin, and Judith D. Chapman, 80-92. Dordrecht: Springer.

Thoreau, Henry. 1854. Walden; or Life in the Woods. Boston: Ticknor and Fields.
Treanor, Brian. 2010. "Environmentalism and Public Virtue." In Virtue Ethics and the Environment, edited by Philip Cafaro, and Ronald Sandler, 9-28. Dordrecht: Springer.

Treanor, Brian. 2014. Emplotting Virtue: A Narrative Approach to Environmental Virtue Ethics. Albany: SUNY Press.

van Wensveen, Louke. 2000. Dirty Virtues: The Emergence of Ecological Virtue Ethics. Amherst: Prometheus Books.

van Wensveen, Louke. 2001. "Ecosystem Sustainability as a Criterion for Genuine Virtue." Environmental Ethics 3: 227-241.

Wolicka, Elżbieta. 1994. Mimetyka i mitologia Platona. Lublin: TN KUL.

Zawojska, Teresa. 2017. „Arystotelesowska koncepcja człowieka podstawą racjonalnej działalności gospodarczej." Zeszyty Naukowe Szkoty Głównej Gospodarstwa Wiejskiego. Ekonomika i Organizacja Gospodarki Żywnościowej 117: 5-18.

Zuziak, Władysław. 2006. „Kształtowanie się osoby w wymiarze moralnym." W Wokót tożsamości człowieka, red. Władysław Zuziak, 91-109. Kraków: Wydawnictwo Naukowe PAT. 